References:

1. Asmus V.F. Berkli // BSJe, t. 3. - M.: Sovetskaja jenciklopedija, 1970. - s. 695 - 696.

2. Batuev A.S. Fiziologija vysshej nervnoj dejatel'nosti i sensornyh sistem. - SPb.: Piter, 2006. $-317 \mathrm{~s}$.

3. Anohin P.K. Pavlov I.P. // Bol'shaja sovetskaja jenciklopedija. M.: «Sovetskaja jenciklopedija», t. 19. 1975. S. $176-179$.

4. Gavrilov V.V. Sravnitel'naja psihofiziologija // Psihofiziologija. Pod red. Ju.I. Aleksandrova. SPb.: Piter, 2007. S. 373 - 384.

5. Kjendel Je. Kletochnye osnovy povedenija. M.: Mir, 1980. 598 s.

6. Ivanickij A.M. Psihofiziologija soznanija // Osnovy psihofiziologii, gl. 11. M.: INFRA-M, 1998. S. $202-219$.

7. Sechenov I.M. Fiziologija vysshej nervnoj dejatel'nosti // Izbrannye proizvedenija T.2. M.: Izd-vo Akademii nauk SSSR, 1956. $940 \mathrm{~s}$.

8. Jengel's F. Dialektika prirody. M.: Izd-vo CK VKP(b), 1934. 300 s.

9. Rumjanceva T.G. Bekon F. // Vsemirnaja jenciklopedija: Filosofija. M.: AST Mn.:Harvest, Sovremennyj literator 2001. S. $147-149$.

10. Pahomov B.Ja. Jevoljucija - razvitie - strukturnye urovni materii // Trudy III vsesojuznogo soveshhanija po filosofskim voprosam sovremennogo estestvoznanija. M.: Nauka, 1983. S. 243-246.

11. Kedrov B.M. Kriterii razlichenija vysshih i nizshih form dvizhenija materii // Prostranstvo, vremja, dvizhenie. Dialekticheskij materializm i sovremennoe estestvoznanie. M.: Nauka, 1971. S. 326-343.

Статья отправлена: 24.05.2017 г.

(C) Карачунский В.А.

ЦИТ: иа217-055

DOI: 10.21893/2415-7538.2017-06-3-055

Халявка Л.В

КОНЦЕПТ УКРАЇНА В АНГЛОМОВНОМУ ПУБЛЦИСТИЧНОМУ ДИСКУРСІ

Полтавський національний педагогічний університет імені В.Г.Короленка Lidiia Khaliavka

THE CONCEPT UKRAINE IN THE ENGLISH JOURNALISTIC DISCOURSE

У статті розглядається особливості використання концепту УКРАЇНА в англомовному публіцистичному дискурсі в контексті лінгвопрагматичного аналізу. Актуальність дослідження полягає в аналізі арсеналу лінгвістичних засобів, якими користуються журналісти, публічисти, та ролі изих засобів у формуванні іміджу України з метою свідомого та несвідомого сугестивного впливу на читача.

Ключові слова: концепт, метафора, поле, сфера-джерело, картина світу, тематичні блоки.

The article deals with peculiarities of using concept UKRAINE in Englishlanguage journalistic discourse in the context of linguistic pragmatic analysis. Relevance of the research consists in the analysis of linguistic arsenal of means, which are used by journalists, publicists, and the role of these ones in shaping the image of Ukraine for the purpose of of conscious and unconscious suggestive 
influence on the reader

Key words: concept, metaphor, field, field-source world view, themed units.

В Україні в умовах кардинальних геополітичних змін постійно зароджуються нові об'єкти внутрішнього і зовнішнього світу, а 3 цими сутностями з'являються нові смисли. Вони повинні бути позначені новими мовними одиницями. Метафорика ж найбільш продуктивний спосіб позначення, що спирається на вже існуючі лексичні одиниці і при перенесенні 3 одної сфери в іншу набувають нових смислів та додаткової образності. Проблеми метафоризації знаходяться в центрі уваги дослідників [2] оскільки метафора є універсальним способом категоризації.

В умовах кризового стану збільшується частотність використання метафор [1, с. 45]. Метафора - неодмінний показник кризових настроїв соціальнополітичного життя, що дозволяє простежити періоди підйому i спаду суспільного напруження. А політична ситуація. що склалася в Україні яскраво ілюструє їх використання в політичних текстах засобів масової інформації (далі - 3МI) різних країн.

Концептуальна метафора $\epsilon$ використання знака однієї концептуальної сфери на позначення складника іншої, притаманної повсякденній мові й мисленню людини і керується набутим у процесі спільної діяльності етносу досвідом [1, с. 46].

Нами було досліджено ряд американських та британських 3MI, a найяскравіші концептуальні метафори (90 метафор американських 3MI і 28 британської преси) були розподілені на 6 тематичних блоків ЛЮДИНА, ВІЙНА, ДОРОГА, КРИЗА, ОСВІТА.

Проілюструємо найбільш репрезентовані тематичні групи.

Метафорична картина світу, що створила людина, $є$ в певній мірі антропометричною. У американській та британській пресі як попередніх років, так і зараз Україна зображується у вигляді людини (персоніфіковано). Людина метафорично створює (концептуалізує) картину країни у вигляді тіла, складових органів, якостей, фізіологічних дій та потреб. Антропоцентрична спрямованість мови авторів виявлясться в низці метафоричних виразів в американських та британських виданнях. В цьому тематичному блоці їх можна розділити на 2 підгрупи:

Асоціації з особистістю в американських виданнях, наприклад: “Ukraine signed, Ukraine agreed, Kiev might want to turn back the clock, Ukraine has been mobilizing a national guard" (USA Today); "Ukraine appeals to the West, Ukraine accuses Russia, Ukraine counts on NATO allies, Ukraine looks to Furnpe, Ukraine cannot pay such a political, uneconomic price" (Chicago Tribune); Ukraine is big deal (Los Angeles Times) та в британських: "Ukraine is on verge" (Daily Express); "EU to embrace Ukraine" (The Daily Telegraph); "Kiev has accused Moscow" (The Guardian); "Ukraine signs EU deal, Ukraine tied its future closer to Europe" (Times Online); "Ukraine will pursue; Ukraine is now pushing; Ukraine insists; Ukraine prepares to push" (Інтернет блог), тощо. Асоціації з людиною, іiі органами та якостями (в американських ЗМІ, наприклад: “...voices for human dignity (Los Angeles Times); "Restoring legitimacy in the eyes of the Ukrainians, the 
independence movement was born" (USA Today) та в британських: “...keeping an eye on the Crimea results, the Ukrainian character" (The Guardian), тощо.

Отже, Україна і ії населення уподібнюється одній істоті або особистості, що має органи, голос і характер та може виконувати певні функції. Вона виступає як єдине ціле 3 народом i приймає рішення разом 3 ним. Антропометрична спрямованість американської та британської преси підтверджується вищенаведеними прикладами, які складають 20\% та 46,43\% відповідно від загальної кількості метафоричних виразів.

Але на цьому етапі розвиту держави та військового конфлікту на Сході країни, закордонні ЗМІ та політичні діячі почали відокремлювати народ від України, а також загострювати увагу на відокремленості країни від Росії, наприклад: "The Ukrainian people deserve the opportunity to determine their own future" (CNN); "But the Ukrainian people have also reminded us that human beings have universal right to determine their own future" (CNN); "Fighting between Ukrainian forces and pro-Russian rebels in the area known as Donbass" (Інтернет блог).

Сфера-джерело ВІЙНА представлена великою кількістю метафор в американській пресі. Україна знаходиться в кризовому стані, тому в такій ситуації відбувається концептуалізація в термінах військової метафори. Тобто, формуються переносні значення слів і словосполучень, що взяті зі сфери військової термінології. Метафори даної групи можуть бути розподілені на такі, що показують відношення Росії до України, такі, що демонструють стан в Україні.

Отже, метафори, що показують ситуацію в Україні, зосереджені в статтях американських ЗМI, наприклад: "Ukraine would have difficulty fighting off a Russian incursion, East-West confrontation. Ukraine has been struggling to maintain its indepetulence"; "The Ukrainian people are fighting for their freedom" (USA Today); "Military movements taken by the Russian Federation inside of Ukraine" (CNN); "However, it has criticized the current Ukrainian government, saying it is the result of a coup, and expressed alarm over attacks on ethnic Russians there that the United Nations has called exaggerated" (New York Times), тощо. Тут ситуація, хоч і $є$ гострою, та все ж небезнадійною. Зустрічаються такі лексичні одиниці як "fight" і "straggle", які по шкалі інтенсивності військової лексики $\epsilon$ посередніми. У текстах статей американських ЗМІ можна знайти метафори, що характеризують ситуацію в Криму, наприклад: “Crimea is not another Cold War, This is not another Cold War that we are entering into Crimea is a "contest of ideas" (Los Angeles Times). Як бачимо, Крим не $\epsilon$ ще одним місцем Холодної війни, а всього лише боротьба інтересів, тому й “загарбання” Криму не сприймається серйозно.

У метафорах, що ілюструють стосунки між Україною та Росією, все частіше зустрічаються такі лексичні одиниці як "fighting", destabilization, "confrontation" у американській пресі та "war" в газетах обох країн. Метафори в американській пресі, наприклад: "Ukraine locked in confrontation with Russia" (Chicago Tribune); "sparking war" (Los Angeles Times); "violent fascists and thugs trying to destroy a culture" (USA Today), тощо та в британській пресі: higher food 
costs could spark wars (The Daily Telegraph); "energy war heats up, conflict was entering a "military stage»" (Times Online), fighting between Ukrainian forces and pro-Russian rebels in the area known as Donbass (Інтернет блог), Ukraine will pursue prosecutions against Russia in the International Court of Justice (Інтернет блог), тощо. Як бачимо, самі стосунки переростають у стадію війни, метафори складають 25,56\% американських і 10,71\% британських одиниць від загальної кількості виявлених метафор.

Суспільне життя в Україні метафорично уявляється як вистава, шоу, представлена трагічним жанром. Театральна метафора підкреслює трагічність ситуації в країні під час кризовою стану. В американській пресі присутні такі метафори, наприклад: "major tragedy"; "All the world is watching Ukraine"; "This is the most dramatic period in the history of Ukraine" (USA Today); "Painted a sorry picture" (Chicago Tribune); "Crimea's "tragedy" wouldn't have happened on my watch, Russia s annexation of Crimea a "a major tragedy""; "Crimea is a tragedy, a major tragedy (New York Daily News) та "the conflict could herald a new Iron Curtain over Europe" (Daily Express) в британській газеті. Таким чином, найчастіше зустрічаються лексичні одиниці 3 грагічним і сумним смислом. Метафора оркестру: "Ukraine accuses Russia of orchestrating separatist moves" (Chicago Tribune) вказує на те, що усім цим театром керує Росія. Метафори даного блоку складають 10\% американських та 3,57\% британських одиниць від загальної кількості виявлених метафор.

Отже, в результаті класифікаційного аналізу концептуальної метафорики досліджуваного матеріалу виокремлено 6 тематичних блоків: ЛЮДИНА, ВІЙНА, ДОРОГА, КРИЗА, ОСВІТА. Найчастотнішими сферо-джерелами метафорики кризового стану в Україні виступають такі: ЛЮДИНА, ВІЙНА, ДОРОГА. Найменш уживаними американському газетному тексті $є$ блок OCBITA.

Переважання метафор сфер-джерел ВІЙНИ та ЛЮДИНИ вказує на антропометричну спрямованість мови авторів зображення концепту УКРАЇНА і iї населення як однієї істоти або особистості, яка має органи, голос і характер та може виконувати певні функції. Так, вона виступає як єдине ціле з народом i таким чином, приймає рішення разом з ним. Крім того, Україна знаходиться в кризовому стані, тому в такій ситуації відбувається концептуалізація в термінах військової метафори: тобто, формуються переносні значення слів i словосполучень, що взяті зі сфери військової термінології. Відсутність деяких сфер-джерел не вказує на те, що вони взагалі не існують у свідомості читачів.

Список використаних джерел

1. Боєва Е. В. Актуалізація концепту Україна у поетичному дискурсі Т.Г. Шевченка / Е. В. Боєва // Одеський лінгвістичний вісник. - 2014. вип. 3. - С. 45 50 .

2. Василик Л. С. Концепти Україна та свобода в реалізації національної ідеї: історико-отологічний аспект / Л. С. Василик. - С. 184-189. [Електронний Pесурс]. - $\quad$ Режим доступу. :http://journlib.univ.kiev.ua/index. php?act $=$ article $\&$ article $=2223$ 
3. Гак В. Г. К проблеме сопоставительно-типологического анализа речевого акта и текста / В. Г. Гак // Сопоставительная лингвистика и обучение неродному языку. - М. : Наука, 1987. - С. 37-48.

4. Звегинцев В. А. Язык и лингвистическая теория / В. А. Звегинцев. М. : Эдиториал УРСС, 2001. - 248 c.

5. Мудраченко Т. Б. Актуалізація концепту УКРАЇНА в сучасному англомовному медійному дискурсі : автореф. дис. на здобуття наук. ступеня канд. філол. наук : спец. 10.02.04 “Германські мови” / Мудраченко Тетяна Борисівна. - Харків, 2013. - 23 с.

6. Мудраченко Т. Б. Базові референти концепту УКРАЇНА в англомовному публіцистичному дискурсі / Т. Б. Мудраченко // Науковий вісник Волинського нац. ун-ту імені Лесі Українки / Волин. нац. ун-т ім. Лесі Українки ; [редкол.: Г. Л. Аркушин та ін.]. - Луцьк, 2011. - № 3 : Філологічні науки. Мовознавство, Ч. 1. - С. $126-129$.

\section{ЦИТ: иа217-066}

DOI: 10.21893/2415-7538.2017-06-3-066

УДК 811.161.2'282(477.41/.42)

Марєев Д. А. ТЕНДЕНЦІЇ РОЗВИТКУ ЗАЙМЕННИКІВ У СХІДНОПОЛІСЬКОМУ ДІАЛЕКТІ УКРАЇНСЬКОЇ МОВИ

Глухівський національний педагогічний університет ім. О. Довженка

Глухів, Києво-Московська 24, 41400

Mareyev D.A.

DEVELOPMENT TRENDS IN PRONOUNS OF EAST-POLESSIAN DIALECT OF UKRAINIAN LANGUAGE

Oleksandr Dovzhenko Hlukhiv National Pedagogical University Hlukhiv, Kyevo-Moskovska 24, 41400

Анотація. У статті подано спостереження над динамікою окремих займенників та їх ареали у східнополіському діалекті украӥнської мови. На підставі аналізу мовного матеріалу встановлено, що суттєвий вплив на зміни у вживанні прономенів має південне наріччя, яке підтримує просування на північ низки форм, властивих літературній мові. Зосереджено увагу й на впливові інших суміжних говірок (украӥнських, російських та білоруських). Визначено роль фонетичних змін в тенденціях розвитку займенникової словозміни.

Ключові слова: східнополіський діалект, ареал, займенник, мовна динаміка, тендениії розвитку.

Abstract. The article presents observations on the dynamics of individual pronouns in the East-Polessian dialect of the Ukrainian language. The areas of the distribution of some pronouns have been traced. Based on the analysis of linguistic material, it was revealed that the southern dialect has a significant influence on the changes in the use of pronouns, which supports the advancement of a number of forms of pronouns inherent in the literary language to the north. In addition, the influence of other related Ukrainian, Belarusian and Russian dialects was revealed. 